Raúl Ruiz, Diario. Notas, recuerdos y secuencias de cosas vistas (19932011), edición de Bruno Cuneo (Santiago: UDP, 2017).

RESEÑA

\title{
MUCHAS VIDAS Y UNA SOLA MUERTE
}

\section{Ascanio Cavallo}

Crítico de cine

a primera pregunta que emerge ante las 1.212 páginas del Diario. Notas, recuerdos y secuencias de cosas vistas (1993-2011), de Raúl Ruiz, primorosamente editadas por Bruno Cuneo (Santiago: UDP, 2017), ${ }^{1}$ es si ofrecen algún acceso al mundo del más importante de los cineastas chilenos. La respuesta es sí, pero a condición de entender que se trata de un mundo laberíntico, amoblado no sólo con referencias, sino sobre todo con resonancias, ecos, repiques, rebotes que ni cinco mil páginas podrían agotar. El mundo de Ruiz fue un flujo tumultuoso de lo que Freud denominó, en su Interpretación de los sueños, “copiosas conexiones asociativas" y parece seguro que nadie llegará a conocerlo enteramente, con la excepción de Valeria Sarmiento, su esposa por más de cuatro décadas.

En Ruiz convergen dos figuras que la modernidad ha vuelto antitéticas: el intelectual y el artista. En su caso, ambas se revisten con una armadura de erudición. Es, por así decirlo, una modernización del humanismo renacentista, que vuelve a combinar el interés por la es-

Ascanio Cavallo. Periodista de la Universidad de Chile. Columnista político del diario La Tercera y crítico de cine de la revista Sábado de El Mercurio. Director de la Colección Cine de Uqbar Editores. Ex director del diario La Época y de revista Hoy. Entre sus libros figuran La historia oculta del régimen militar, con Manuel Salazar y Óscar Sepúlveda (1988), y La historia oculta de la transición (1998). Email: ascanio.cavallo@tironiasociados.com.

${ }^{1}$ Este libro es complementario con otro anterior, una valiosa recapitulación de entrevistas y declaraciones también editada por Bruno Cuneo: Ruiz. Entrevistas escogidas, filmografia comentada (Santiago: UDP, 2013). 
peculación intelectual (por ejemplo, el juego) con el de la ciencia (por ejemplo, la física), al mismo tiempo que promueve la indistinción entre materiales "nobles" y "vulgares", siguiendo el rastro de Parra. Ruiz fue la cabeza más rara que haya producido Chile y el Diario ofrece una ventana hacia su interior.

Cuando apenas ha cumplido los 54 años, en diciembre de 1995, volando entre Taipei y Bangkok, se pregunta: “¿Cuántas películas me quedan por filmar? ¿La última?". ${ }^{2}$ Y luego agrega, como para que el lector salga del sobresalto: "Serenidad y tristeza". No se puede descartar que en aquellos días estuviera bajo la influencia de Comédie des ombres, la única película que rodó en mandarín y que transcurría principalmente en un cementerio.

El proyecto era otra rareza: combinaba cuentos del filósofo chino del siglo IV a.C. Chuang Tseu (o Zhuangzi) con relatos folclóricos chilenos. Al fin, pasó a engrosar la nómina de obras inconclusas de Ruiz, que no es breve. Pero eso no se sabía en el momento en que regresaba de Taiwán, y en cambio a mediados de ese año había concluido el "confortable" rodaje de Tres vidas y una sola muerte, una de las cintas postreras de Marcello Mastroianni, y pronto iniciaría la preparación de Genealogías de un crimen, con Catherine Deneuve y Michel Piccoli, completando el período más estelar de su carrera.

No era un momento para andar pesimista, pero lo que el sombrío Ruiz recuerda es que durante el trabajo con Mastroianni comenzó a detectar un ligero temblor de manos. El Diario es, entre muchísimas otras cosas, el retrato de un hipocondríaco que, sin embargo, no lo teme demasiado a la muerte. Es un hombre extremadamente atento a las señales de su cuerpo. A los 52, cuando se inician estos escritos, su principal dolencia es la diabetes; más tarde, según pasan los años, se agregarán otras.

Ahora se conoce la respuesta a su pregunta: le quedaban todavía unas 35 películas completas, esto es, alrededor de un tercio de la filmografía que se ha logrado establecer tras su muerte, el 19 de agosto del 2011, con 70 años recién cumplidos.

${ }^{2}$ Raúl Ruiz, Diario. Notas, recuerdos y secuencias de cosas vistas (19932011). Edición de Bruno Cuneo (Santiago: UDP, 2017), volumen I, 105. En adelante, el Diario se citará tan sólo con el número de página entre paréntesis, antecedido del volumen. 
¿Se puede ser hipocondríaco sin temerle a la muerte? Éste es un asunto que merecería mayor discusión, pero la hipocondría de Ruiz tiene un lado cómico. El 28 de junio de 1996 confiesa: "Hace un par de días me encontré con Pascal [Bonitzer] para modificar el guión. Hablamos de una cosa y de otra y de repente le dejé caer lo siguiente: 'Tengo los síntomas de un cáncer a la garganta, pero, al mismo tiempo, los conozco y puede ser que me los esté inventando'. Me dijo que hace dos años él tenía los mismos síntomas y que resultaron ser angustia. Pero se ha alarmado" (I, 116).

El porfiado cáncer "que nadie quiere ver" se esfuma en las páginas siguientes, aunque Ruiz suele sentirse rodeado por la muerte. La muerte es uno de sus principales tropos y su estética está cargada de una imaginación fúnebre, a veces cómica, a veces melancólica, pero siempre intensamente perturbadora.

Uno de los pasajes más duros del Diario ocurre en los primeros meses de 1998, cuando su padre, "el Capitán", inicia su camino a la muerte. El primero de abril de ese año se registra esta seca entrada: "Llegué a las 13 hrs. Vi a mi padre agonizar. Murió a las 20 hrs." (I, 270). Nueve días más tarde: "Ayer vinieron a almorzar Manuel Silva y José Román. Aparente alegría. En cada rincón de la casa acecha la muerte" (I, 274).

En las elusivas páginas que dedica a este suceso aparece el intenso afecto de Ruiz por el capitán de la marina mercante que le abrió el mundo en los años cuarenta y cincuenta, cuando el mundo estaba lejos de Chile, y de pronto se vuelve lamentable que el Diario sólo se inicie diez años después del rodaje de Les trois couronnes du matelot, una de sus películas más barrocas y brillantes, y también más secretamente ligada al "Capitán".

En el 2008 muere también su madre, y esta vez Ruiz escribe más, combinación de inquietud y humor. En el lugar más banal de la casa, un corredor con forma de ele, siente que su madre muerta se hace presente. “¿Qué sentí? Casi nada: una presencia detrás de mí. Y un erizarse de los pelos de la nuca. Y un escalofrío. Y, por supuesto, miedo" (II, 529). Otras cosas raras ocurren, con el despertador, el teléfono, la cocina. Ruiz no duda: su madre está penando. Y entonces: "Mi tía dijo: 'Siempre es así, pero nunca dura más de una semana"” (II, 530).

La muerte aparece en serio, con dureza, a partir de 2009, momento en el cual adquiere una brusca materialidad algo que el lector sabe 
pero tiende a olvidar en el océano de páginas: que el Diario se termina cuando muere su autor. Aunque no pierde lucidez ni energía, desde entonces la escritura se hace más breve y esporádica, como marcando el paulatino retroceso de su autor hacia su propio final: 26 páginas para ese año, que disminuyen a 14 en 2010 y a sólo 10 en lo que alcanza a vivir de 2011. La última anotación es del 5 de julio de 2011. Ruiz murió 45 días después, mientras preparaba uno de sus proyectos de mayor presupuesto, Las líneas de Wellington, que por recomendación de John Malkovich terminó dirigiendo Valeria Sarmiento.

$* * * * *$

Chile es un problema sin solución. De todos los artistas e intelectuales que se fueron al exilio con el golpe de Estado, Ruiz es el único que no lo vivió como un sufrimiento. Su relación con Chile es fluctuante, pero es claro que considera que, si no se hubiese ido del país a los 32 años, su carrera fílmica no habría sido posible. "De las pocas cosas que no me arrepiento es de haber huido de América Latina, el continente de la gana y la tristeza (Keyserling dixit)" ( $1^{\circ}$ de marzo de 2003: II, 128). Y más tarde, a fines del 2007: "Hace 34 años que salí de Chile. Veo a Valeria, veo a mi madre (a la que puedo ver todavía viva y muy viva). Las veo en situación de duelo. Lo peor podía esperarse en aquellos años y lo peor fue lo que fue. Fue mejor, mejor que mejor, en el buen y en el mal sentido. Sobre todo, fue" (II, 492).

Primero de febrero de 1997: "Un año en Chile bastaría para matarme. Ayer, mecánicamente quise salir y sólo de pensar en la cara de la gente divagando por la calle preferí volverme a acostar. Vuelvo a sentir la impresión de mi primer viaje después de nueve años de exilio: 'pesadilla a la hora de la siesta"" (I, 136). 5 de mayo de 1998: "Qué raro, la idea de no ver nunca más a un chileno me alegra. ¿Qué querrá decir? Patria, putria, madrematria. El reír infernal de los chilenos y su sed de matar muriendo con tal de que nada quede. Chile habría declarado la guerra atómica por el puro placer de hacerlo" (I, 295).

Ese "temor a Chile" es tan penetrante, que lo siente con sólo subir al avión rumbo a Chile: "La misma sonrisa satisfecha y cínica de mis compatriotas. De nuevo la misma sensación de cada vez que voy a Chile: ¡de la que me salvé!" (8 de abril de 2003: II, 144). 
La huella del exilio se siente con más fuerza en su crítica ambivalente de la transición política, que ejerce con el desapego consciente de un artista que sólo ve desde París sus peripecias y el papel que asume en ellas su partido, el Socialista. "En todo caso, la mayoría de los buenos saben que estamos en peligro y que nuestros enemigos son... nuestros amigos. El socialismo ha asesinado todo lo que de cerca o de lejos se parece a la privada empresa de crear arte. El muy mal llamado socialismo. Apocalipsis de pacotilla. 'Callada canalla' (como diría Braulio [Arenas] en sus delirios anti-UP). Igual no cambiaré. Estoy muy viejo para darme vuelta la chaqueta. Pero duele como el cepo la memorable traición de los míos. Ominami-O my money. Aylwin-Pinochet, FreiFrei” (7 de febrero de 1994: I, 61). En verdad, su refriega con el PS es mucho más corrosiva en algunas de sus películas: Mémoire des apparences (1987) y La telenovela errante (1990), y el guión de Secretos (2007), que escribió para Valeria Sarmiento.

El 11 de enero del 2008: "Ayer cené con Roberto y un vestuarista y decorador que trabaja en diferentes teatros de ópera (Metropolitan, Bayreuth, Scala). Me dijo que aquí en Chile no ha conseguido trabajar. Indecisión, chuecura y envidia. Me aconsejó prudencia con las autoridades de la cultura en Chile" (II, 507).

La producción intelectual de la izquierda lo desquicia: "Leí, hojeé rápidamente, la revista Rocinante. El mismo regusto a lata de las revistas de la UP y la misma sensación de que están vendiendo una pomada (pero quién no la vende)" (2 de septiembre de 1999: I, 347). En la misma revista encuentra cinco años más tarde un análisis de Machuca, película a la que llama "unanimista": "Sociología idiota, valga el pleonasmo". Y en el apogeo del libro que inauguró la crítica de la transición -Chile, anatomía de un mito, de Tomás Moulian- se enfurece: "Leo a un malo llamado Moulian. Da que rabiar y te adormece (...) Durante el viaje a Sao Paulo leí algunas páginas de Moulian, cuya incoherencia me puso de mal humor" (5 de octubre de 1998: I, 300-1).

Ruiz salió al exilio sin una persecución evidente, pero en el filo de muchos peligros posibles. El cineasta alemán Peter Lilienthal consiguió que tomara un vuelo hacia Alemania junto con Antonio Skármeta, desde donde luego derivó a París. Regresó a Chile, no después del fin del régimen militar, sino mucho antes, en 1982, cuando incluso filmó uno de sus cortos más memorables, Carta de un cineasta o el retorno de un amateur de bibliotecas. 
Desde entonces, viajó periódicamente a visitar a sus padres y, a veces, a filmar fragmentos sin un motivo predeterminado, como a veces hacía en distintos rincones del planeta. Después de 1990, sus visitas se hicieron más frecuentes - tres y hasta cuatro por año-, junto con los "proyectos chilenos" que resultaban intrigantes para toda la crítica de cine del mundo. Su estatuto había cambiado radicalmente: ya no era un cineasta del destierro, sino una figura "de culto", uno de los pocos a los que Cahiers du Cinéma había dedicado un número especial y al que solicitaban las grandes estrellas (John Hurt, Marcello Mastroianni, Catherine Deneuve, Michel Piccoli, Sharon Stone, Gérard Depardieu, Isabelle Huppert, Emanuelle Béart, John Malkovich, Laetitia Casta) para ganar prestigio, como ocurre con Terrence Malick, Woody Allen o Pedro Almodóvar.

El problemazo de Chile nunca se resuelve. La enorme mayoría de sus películas contiene alguna referencia - un chiste, una canción, una voz, una imagen - que ha de ser enigmática para cualquier espectador que no sea de este país. Es su marca de fábrica. Hitchcock hacía un cameo en todas sus películas. Ruiz convierte a Chile en un cameo.

$* * * * *$

Y entonces, ¿cómo nacían las películas de Ruiz? En el capítulo que le dedica dentro de ¿Qué es el cine moderno?, el crítico australiano Adrian Martin constata que "es imposible saber qué filmes ha visto Ruiz, qué libros ha leído, qué música escucha —usando sin duda estas cosas todo el tiempo como una matriz generativa para sus propias creaciones, también suprime las huellas de esa matriz". ${ }^{3}$

El reclamo de Martin nace de la sospecha de que Ruiz lee mucho, ve mucho cine y oye mucha música. El Diario confirma tanto la imposibilidad como la sospecha. Ruiz lee mucho -incluso colecciona ediciones antiguas - , pero no sigue un patrón visible y todo indica que lee de manera sinóptica y diagonal. Los libros lo acompañan a todas partes y, desde luego, a los rodajes. El 24 de noviembre de 1993, mientras filma Fado majeur et mineur, se halla esta sorprendente reflexión: "Sabiendo que lo que leo durante la filmación suele determinar el carácter

${ }^{3}$ Adrian Martin, ¿Qué es el cine moderno? (Santiago: Uqbar Editores, 2008), 133. 
y hasta el sentido de las escenas, la elección de libros debería ser una tarea responsable. En cambio..." (I, 24).

Con todo, por debajo del torrente de libros que repasa permanecen constantes el filósofo y matemático inglés A.N. Whitehead y, al menos en el período de este Diario, el físico norteamericano David Bohm y el historiador italiano Carlo Ginzburg (que lo lleva a decir en octubre del 2001 que "las preocupaciones que me quitan el sueño son italianas: Santillana, Storoni Mazzolani, Agamben, Cacciari, Sciascia, Ginzburg, Macchia y, por supuesto, Praz (sin olvidar Elémire Zolla y Cristina Campo)" (I, 585). En la literatura, las grandes resonancias son Borges, Kafka, Thackeray, Faulkner, Pound. Y, a lo largo de muchos años, Calderón de la Barca y Tirso de Molina, maestros del sueño y la paradoja que inspiran una y otra vez los retruécanos de Ruiz.

Cuando las enfermedades ya han ganado terreno, en enero de 2010 registra un conmovido homenaje a los textos clásicos: "Me ha hecho muy bien la lectura de los Pensamientos de Pascal (...) iqué fervor y qué serenidad! A veces pienso en sus cilicios, en la tortura de sus enfermedades y las torturas voluntarias. ¿Hay dolores que calmen, que distraigan de esos dolores? ¿Hay jerarquía en el dolor o es un continuo empantanarse, una molestosa impaciencia? Metástasis de la iconostasis" (II, 582).

También es un aficionado incontinente a la música. Un día cualquiera de compras en París, el 28 de febrero de 1997: Conlon Nancarrow, Bach por Stokowski, Reger en la versión de Scherzer, Eddy Duchin, Duke Ellington, Friml, la música de Ed Wood. Nuevamente, hay una obra que atraviesa los años: El clavecín bien temperado, de Bach, en las más diferentes versiones posibles.

Pero cuando se trata de la música que usará en sus películas, lo más importante es la colaboración con Jorge Arriagada, que desde 1977 estuvo presente en casi todas sus obras. Mientras estudia la música para Klimt, en abril del 2005 realiza esta importante anotación: "Como de costumbre, Jorge trabaja su música con una intuición general del film, pero sin componer escenas precisas, lo que, en el fondo, prefiero. Eso nos evita toda forma de jump and fall' (II, 357).

En cambio, no es un cinéfago. Ve películas en forma irregular - se siente culposo cuando deja de hacerlo- y no se subsume en las salas de arte y ensayo. Al contrario, suele ver blockbusters y a veces películas 
infantiles. En los casi 18 años del Diario no llega a hablar de 100 títulos. ${ }^{4}$ Pero tiene una cultura y una memoria educada en los clásicos norteamericanos y en las rupturas europeas de los sesenta. Es lo que podría llamarse un "cinéfilo clásico".

Cuando lo explica, curiosamente, se desliza hacia el amor: “...a mí me cuesta ver films en general y, por lo demás, no culpo a nadie de no tener ganas de ver los míos. En fin, casi. Amo a Valeria. Amo amarla. En fin, casi. Sí, la amo" (1 de diciembre de 1993: I, 36). El amor de Ruiz no se puede disociar de Valeria Sarmiento ni del cine. Después de ensayar decenas de definiciones en las 1.212 páginas, llega a una muy personal el 13 de octubre del 2004: "El cine es mi espejo turbulento" (II, 309).

El 24 de diciembre del 2002 cena en casa de una familia en la que una chica de 15 años desea ser cineasta: "Los padres querían que les hablara de las dificultades y los sufrimientos del cine, pero no pude. El cine debe ser la profesión más entretenida que existe" (II, 92).

Y la conclusión crucial, el 4 de octubre del 2004, en un período en que los problemas con Klimt lo hacen interrogarse con frecuencia por su oficio: "Hoy, día francamente primaveral en Viena. Extraña vida. No puedo quejarme. No puedo amarla. No puedo decir 'no puede ser', porque es. Estoy cumpliendo todo lo que siempre quise. Filmar ficciones en los países de donde vienen los autores que me gustan" (II, 306).

$* * * * *$

En todo momento, cualquiera sea el punto que se escoja, Ruiz está elaborando no menos de cinco proyectos - a veces ocho, o diez- a un mismo tiempo. Muchos cineastas trabajan de la misma manera, con conciencia de que muchas de esas ideas caerán antes de nacer. Una nómina de los proyectos que Ruiz no llegó a realizar sería probablemente varias veces más abundante que su filmografía.

En 48 años de actividad, Ruiz realizó 119 películas (sin contar las inconclusas), lo que es un récord en el cine contemporáneo. Martin Scorsese, por ejemplo, lleva 57, y Woody Allen, 54, por nombrar a dos cineastas altamente productivos. En algunos años, como 1989, Ruiz llegó a realizar siete películas — cortos y largos - y de manera muy frecuente dos o tres por año.

\footnotetext{
${ }^{4}$ Ver "Ruiz, el crítico" en este mismo número de Estudios Públicos.
} 
En algún punto de los ochenta, cuando inició su colaboración con el productor portugués Paulo Branco (Le territoire, 1981), Ruiz tomó la decisión de aceptar lo que se le ofreciera, confiando, por un lado, en que su talento fílmico le permitiría siempre imponer su sello personal y, por otro, en que su propia obra sería un indicio para el tipo de cosas que debían proponerle. Su inspiración era el Luis Buñuel que se instaló en México y revolvió por dentro los géneros de ese cine.

No siempre pudo cumplir con esa intención. El Diario registra el tortuoso rodaje de su única película con Hollywood, Shattered image (1997): "Es un hecho que se me quitaron las ganas de hacer la película y que no volverán salvo milagro. Simplemente la manera de filmar le quita toda sorpresa a la filmación. No hay milagro posible. La más mínima invención es anulada antes de que tenga tiempo de formularla" (27 de agosto de 1997: I, 184). En esa película se arruinó todo. Cuando ve el primer montaje, Ruiz nota el reflejo de la cámara en un espejo. Anota: "Es increíble hasta qué punto Robby [Müller] fue poco profesional. Recuerdo bien que le pedí que se fijara en el reflejo. No quiso hacerlo. De alguna manera, quería que la película saliera mal" (I, 198). Es un apunte amargo, tratándose de uno de los más prestigiosos directores de fotografía del mundo.

Algo similar ocurre en su única incursión en el cine británico, a través de $A$ closed book (2009), con guión del crítico, novelista y amigo Gilbert Adair: "Tengo la sensación de que hay una desconfianza generalizada en todos, en general, y en Gilbert, en particular. Mis ideas se fueron volando lejos. Lástima. Espero que sea el último film en este país de "los espantosos ingleses que odio todavía" (18 de septiembre de 2008: II, 544).

En un par de ocasiones se enfrenta al propio Branco: por sus peticiones "al límite de lo inaceptable" en Ce jour-là (2002) y por la distribución de un montaje abreviado de Klimt (2005), que finalmente ha circulado en dos versiones: la de la producción y la de Ruiz.

También piensa que los productores arruinan su adaptación de Jean Giono, Les âmes fortes (2001). "El sábado (...) irrumpieron en la proyección. Siguió un almuerzo abominable, en el que mostraron todo lo que habían ocultado hasta aquí: pánico, ignorancia, tontería y maldad pura y simple" (I, 451). Y luego, reflexionando en La Habana, donde Valeria Sarmiento concluye una película: "Sensación de angustia que 
se va de a poco con el mojito. En nuestro oficio se come mucha mierda, pero mucha. No encuentro las ganas de seguir haciendo cine. Poco a poco me he dado cuenta de que lo único que interesa a los socios de esta empresa de Les âmes fortes es que yo no haga olas, que no diga, por ejemplo, que el film ha sido intervenido y distorsionado" (27 de marzo del 2001: II, 482).

También le molestan las exigencias de Isabelle Huppert en Comédie de l'innocence (2000). Uno de los episodios más graciosos ocurre con Salman Rushdie, de quien adapta El suelo bajo sus pies durante varios meses. Hasta el 17 de marzo del 2001: "Los cambios pedidos y ejecutados ya por Rushdie son pura y simplemente la totalidad del film. Se puede resumir su actitud en la proposición siguiente: sacar a su servidor del proyecto. Ninguna de mis ideas de puesta en escena es considerada aceptable" (I, 476-477).

La desagradable conclusión es que, tratándose de cine, nadie piensa en otra cosa que el éxito. El público está antes que la obra. Está antes y durante, porque si no la certifica como un éxito, la va asesinando en su proceso de existencia.

$* * * * *$

Otra consecuencia indeseada de este modo de trabajar es que muchos proyectos quedan suspendidos o inconclusos, como lo experimentó muchas veces Orson Welles. Palomita blanca (1973-1992) fue afectada por las circunstancias políticas, pero ése no fue el caso de la recién recuperada La telenovela errante (1990-2017), ni del muy poco visto Tango del viudo (1967), su primer largo, que podría ser restaurado pronto. Edipo y Responso: Homage to Huub Bals (1989-2004) fueron terminadas después de 15 años; Miotte vu par Ruiz (2001) demoró siete; y su única película china, Comédie des ombres (1996), quedó inconclusa, igual que la chilena El pasaporte amarillo (2009).

Con una rara inadvertencia de su propia experiencia, cuando le piden desde Nápoles una conferencia sobre "Lo inconcluso" Ruiz piensa en los casos legendarios: Don Quixote, de Welles; Arruza, de Budd Boetticher... Un mes después, cuando va a exponer el mismo tema en Saint-Malo, ya se ha dado cuenta y empuja hacia la conclusión opuesta: no existen las películas terminadas (excepto quizás las de Bresson, dijo alguna vez), todas podrían derivar en otras. 
Éste es uno de los aspectos capitales del cine de Ruiz: su lucha contra el concepto de "conflicto central" expresa su convicción de que tal conflicto no puede existir porque en el mundo real (o en el real de la psiquis) únicamente existen "conflictos descentrados", que se abren a otros mundos, otros sujetos, otras historias. Su arte expresa una visión del mundo constituida por asociaciones, series, combinaciones, aperturas y - una de sus palabras favoritas-circulaciones.

Estas circulaciones no son abstractas: por ellas pasan las vidas infinitas de cada persona, que sin embargo tienen un cierre concluyente: una sola muerte. La muerte suspende el carrusel de la vida, y el agnóstico Ruiz no encuentra salida a esta constatación, ni siquiera en la física fantástica.

Nadie más ve el cine de esta manera. Y nadie más lo filma así. El cine de Ruiz es de una originalidad tan radical, que sólo con una enorme tenacidad pudo construir una filmografía tan voluptuosa en un medio donde las cosas se comprendían de otra manera. En noviembre de 1993, por ejemplo, recuerda "una discusión con John Hurt y su esposa, Joan, en Estremoz, hace dos años, en que John no conseguía entender cómo se podía hacer films con historia sin servirse de la premise" (I, 24). O esta afirmación, que sonará un poco más familiar para los cinéfilos: “...desde siempre, desde hace más de 30 años, considero al guión y a la buena actuación como los principales obstáculos para transmitir una emoción específicamente cinematográfica" (21 de julio de 1995: I, 97). Otra: "Si en poesía se puede decir que el lenguaje se va de vacaciones, en cine se puede decir que el mundo real se va de vacaciones" (22 de febrero del 2003: II, 126).

Está consciente de la relativa soledad a la que lo llevan sus definiciones: "El gusano que susurra 'lo que haces en cine ya no se hace' se construye un camino hacia la capital federal de mi corazón. Trato de detenerlo repitiendo: 'De todas maneras lo que hago nunca se hizo demasiado'. Nada que hacer. Una nueva generación de cinéfilos se encoge de hombros frente a mis collages y caleidoscopios" ( 2 de diciembre de 1993: I, 36-37).

El 24 de septiembre de 2002, terminando el festival de San Sebastián: "Pasaron ayer las seis horas de Cofralandes y fueron vistas por poquísima gente. En el último episodio, que es el que me gusta más, no había nadie. (...) Hay que rendirse a la evidencia de que mis films no 
interesan nada. Los únicos curiosos, aparte de los amigos, eran franceses. He tratado de leer un poco, pero las comilonas me han abotargado el seso" (II, 62).

Esta jubilación melodramática tiene poco que ver con la posición que Ruiz alcanzó en las grandes ligas de la cultura europea. Fue un hombre que pudo registrar un cierto día cualquiera, digamos el $1^{\circ}$ de diciembre de 2000, esta agenda: almuerzo con Santiago Amigorena y Salman Rushdie; tarde con Paolo Branco; y cena con Giorgio Agamben. O, en otro día cualquiera, almuerzo con el crítico Philip Lopate intervenido por el cineasta israelí Amos Gitai y el productor Tom Luddy, quien los arrastra a todos a un pícnic por el cumpleaños de Werner Herzog, donde ya están Otar Iosseliani, Elia Kazan “y otros” (5 de septiembre de 1999).

Y, como hijo de sus tiempos, añora también la fiebre de otras épocas, según anota en noviembre de 1997: "Nuestro oficio o arte está desapareciendo. Nada queda del entusiasmo de los años 60 por la remoción de un cine anquilosado. Hoy lo está más que nunca (comprendido el que yo hago). No hay magia en nuestro trabajo" (I, 204).

Hay que tomar con pinzas estas ráfagas de pesimismo. Un recuento no exhaustivo de sus juicios sobre sus propias películas deja ver el recuerdo feliz de L'hypothèse du tableau volé (1978), la película que lo instaló en la cultura francesa; la felicidad de los rodajes de Les trois couronnes du matelot (1983) y Le temps retrouvé (1999); la alegría de haber logrado excelentes resultados con bajísimos presupuestos en $L e$ territoire (1981) y Viaggio clandestino - Vite de santi e di peccatori (1994); la memoria contenta del trabajoso documental Miotte vu par Ruiz (2002); el orgullo artístico por La chouette aveugle (1987) y Combat d'amour en songe (2000); los sentimientos personales envueltos en Le domaine perdu (2005); la satisfacción con los "proyectos chilenos", Días de campo (2004) y las series Cofralandes (2002), La recta provincia (2007) y Litoral (2008); la melancolía por los días de Trois vies et une seule mort (1996), muy vinculada al recuerdo de Mastroianni...

La filmografía de Ruiz es la clamorosa victoria de un artista por sobre la rapacería y el facilismo.

$* * * * *$

El "método" de Ruiz es lo más cercano a rumiar. Enfrentado a un proyecto cualquiera, piensa, lee, conversa, oye música, mira pinturas, 
divaga. Frente al desafío más grande de su carrera, adaptar la principal obra de Proust, pasa meses sin hallar la forma de abordarlo. Hasta el 21 de marzo de 1997: "Conversación con Emilio [del Solar]. ${ }^{5}$ En un momento me dice: 'El tiempo recobrado es un texto místico' y esta sola frase me abre los ojos: es lo único que me ha interesado en este libro, que leo con tanta dificultad desde hace dos años buscando encontrar un equivalente fílmico. Inmediatamente me levanto de la mesa y llamo a Paulo y en dos minutos nos ponemos de acuerdo. Será el próximo film" (I, 148).

Durante la primera mitad de 1998, los problemas que plantea la adaptación de Proust se toman el mundo de Ruiz. En paralelo, escribe poesía (en algún momento habla de unos 400 sonetos, más siete novelas a la espera) y se intensifica el sentimiento de la muerte. Pero Ruiz lleva sus notas en cuadernos livianos, y a menudo los pierde. Todas las ideas del proyecto escritas entre abril y septiembre de 1998 están entre esas pérdidas.

El 27 de septiembre: "Están casi todos los actores que dan que hablar, y no los he buscado verdaderamente. Se ha producido un torbellino de interés en torno a la cosa proustiana. Y aquí me encuentro, como siempre, sin la plata necesaria pero con el presupuesto más 'consecuente' que un latinoamericano haya tenido jamás" (I, 298).

$\mathrm{Y}$ al día siguiente: "Tengo en claro que he conseguido algo así como el equivalente visual del estilo de Proust y, al mismo tiempo, un condensado de mis propios tics de estilo. Todo lo que sé hacer en cine lo he puesto ahí (y no es poco)" (I, 300).

En noviembre, ya avanzado el rodaje: “...tengo la sensación (y no soy el único) de que la inspiración y la gracia han tocado a este film. Hacía años que no había sentido un film tan desde dentro. Todo en él me parece ahora evidente, emocionante. Es como hacer de nuevo mi primer film. Por otro lado, los resultados, desde un punto de vista técnico, son muy buenos. Ricardo [Aronovich] parece feliz de hacer libremente la luz que le gusta. La realidad es ésa. Todos han sabido servirse de la libertad que les doy" (I, 309).

${ }^{5}$ Junto con el poeta Waldo Rojas, vecino y compañero de juventud, el amigo chileno más influyente de Ruiz en París parece ser Emilio del Solar, matemático, músico e hijo del escritor Hernán del Solar, cuyos cuentos inspiran La noche de enfrente. 
Se trata, eso sí, de un caso excepcional. Valeria Sarmiento dice que no había visto a su marido tan contento desde Les trois couronnes $d u$ matelot, otra de sus obras maestras.

Pero antes de un año, en el rodaje de una de sus películas favoritas, Combat d'amour en songe (2000), hay otro momento parecido: "Dos días felices de filmación. Se produjo el déclic y la imaginación visual, que permite multiplicar el sentido, y la intensidad de las escenas escritas empezó a ponerse en marcha. Acácio [de Almeida] le perdió el miedo al uso de espejos y de split, mesmerizer y otros artefactos. Los actores entraron completamente en el juego" (I, 391).

Aunque a Ruiz le suscita sentimientos encontrados, la evolución del rodaje de Ce jour-là es cautivante. 15 de septiembre del 2002: "Anoche se precipitó la primera imagen de Ce jour-là: una gota de agua que cae sobre la mejilla de Livia cuando encuentra por primera vez al loco asesino y todas las posibles declinaciones de la gota de agua" (II, 61). 16 de octubre: "Tercer día de filmación en el café de Saint-Georges. Todavía no he tenido tiempo de hacer 'cantar' al decorado (...) Todavía no he conseguido darle un ritmo particular a los diálogos del café. Siempre termina por salir a flote el diálogo ligado, demasiado ligado" (II, 68). 9 de noviembre: "Ayer tuve un día que dio el tono a todo el film. Un verdadero salto en el vacío. Sin redes. Creo que está ganado. En el viaje de vuelta (...) tuve sueños en los que se mezclaban el film y otras imágenes terribles. No se filma el crimen impunemente" (II, 73).

La cuestión del déclic, el momento cuando todo fragua, es central en el "método" Ruiz. El Diario registra numerosos casos en que, durante el sueño, al despertar o en momentos inesperados, Ruiz ve el film, es decir, lo completa en su imaginación, aun cuando pueda al mismo tiempo estar tan incompleto como el guión de Nucingen Haus (2008): "Siempre me sorprendo al escribir las últimas páginas de un guión y darme cuenta de que no sospechaba tal final hasta horas antes, a veces minutos antes, de poner la palabra FIN. Empiezo a filmar en diez días" (II, 476).

En otros pocos casos hay un accidente desencadenante, como el 27 de noviembre del 2006, en el aeropuerto de Londres camino a Madrid: "Leí lo siguiente en Fantasmas y almas en pena de Lecouteux: alguien encuentra un fémur seco. Lo usa para hacer una flauta. La flauta canta y cantando pide venganza contra aquellos que lo han asesinado" (II, 453- 
4). Unas semanas más tarde, la imagen deviene central en el rodaje de La recta provincia (2007), la serie de cuatro capítulos que constituirá su más joyeuse reconciliación con Chile.

Todos los que trabajaron con Ruiz recuerdan sus repentinas ausencias del rodaje, de las que regresaba con diálogos nuevos, recién inventados, muchas veces para cambios radicales en la trama. Este lado de cineasta lúdico, improvisador, se combinó siempre de una extraña manera con el profesional que siempre llevaba su fotómetro para medir la luz circundante y que disponía ángulos y focos de la cámara con estricta seguridad.

Lo que Ruiz amaba más del cine eran los rodajes, los momentos que disfrutaba y, según parece, que también gozaban sus equipos. Catherine Deneuve consideró que "se hizo justicia" cuando supo que tendría un papel en Le temps retrouvé, Sharon Stone se ofreció para trabajar en $A$ closed book y Michel Piccoli se entusiasmó con muchas de sus ideas no realizadas. Entre los fotógrafos, pasó a ser una leyenda después de trabajar con Henri Alekan en los 70. Y entre decoradores y vestuaristas era no menos que un titán.

Valeria Sarmiento puso en el comienzo y el final de la reconstituida La telenovela errante algunas imágenes del rodaje que dejan ver la gloria de la filmación. Mejor aún, dejó en el cierre de su película póstuma, La noche de enfrente (2011), la voz de Ruiz ordenando " ¡Rompan filas!” y “¡Corten!”, un instante escalofriante que parece introducir a la película en otra dimensión, inabarcable, imposible.

Con todo, lo más importante en el caso de La noche de enfrente, cuyo rodaje termina tres meses antes de la muerte de Ruiz, es que el equipo advierte lo que está por suceder sin que el mismo director se dé cuenta de ello. Así relata ese homenaje, el $1^{\circ}$ de mayo del 2011: "No es más que una pequeña libreta de notas escolares, en la que cada cual escribió algunas líneas de despedida. Y ahí está el problema. Me siento despedido, llorado, añorado. Gran consuelo, sin embargo: los miembros más modestos del equipo, los obreros, vestuaristas, maquilladoras y asistentes, usan como elogio la palabra 'humilde'. Sonrisa y humildad. Yo no me veo ni muy sonriente ni muy humilde, pero parece que así me ven. Tanto mejor" (II, 602). 
El Diario deja muy en claro que Ruiz se consideraba, más que un cineasta, un artista. Hizo teatro, danza, iópera!, instalaciones, novela, poesía, teoría y hasta algo de música. No aceptaba ser medido o comparado de manera liviana. En el matrimonio de Melvil Poupaud, el 11 de julio de 1999, se encuentra con un sobrino de Proust cuya familia había intentado frenar judicialmente el proyecto de Le temps retrouvé: "En un momento me dijo: 'Lo que más lamento es que Visconti no haya hecho el film'. Yo le contesté: 'Es mejor que lo haya hecho yo, primero porque soy mejor, y segundo porque Visconti era aristócrata y no tenía la distancia ni la oblicuidad de un pequeño burgués como usted y como yo" (I, 333).

Los elogios no lo dejan indiferente. El mismo Poupaud le cuenta, en diciembre de 1993, que el crítico y cineasta Luc Moullet lo considera su cineasta favorito y que ha visto La lechuza ciega más de 10 veces. "En fin, estas cosas suben el ánimo" (I, 49).

23 de marzo del 2000: "Leí el texto que [Charles] Tesson escribió sobre mis films y es impresionante la cantidad de films míos que ha visto. Me ha dicho cosas muy simpáticas, muy emocionado. No supe mucho qué contestar. A Emmanuelle [Béart] le dijo que sólo Fellini y Kurosawa lo habían impresionado tanto como su servidor. Ayuda en estos tiempos duros" (I, 403-4). Y, con más humor, el 10 de marzo de 1995: “Todos me repiten que soy 'muy conocido en Taiwán'. Pero yo he escuchado eso antes en Palermo y en Atenas" (I, 69).

No es sólo esto: le importa tanto la valoración de algunos críticos, que traba amistad con ellos, hasta un punto que desborda la ya extraordinaria sociabilidad de Ruiz, su naturaleza de conversador y flâneur. La excepción resonante es Cahiers du Cinéma, a la que detesta, y es una lástima que el Diario no registre el momento y el motivo de su ruptura con la revista que lo consagró como uno de los cineastas canónicos en su legendario número monográfico de 1983. En cambio, siente simpatía por su eterno rival, Positif, y por su fundador: "Hablé con Michel Ciment, que había visto Une place parmi les vivants. Me dijo: 'Conseguiste sorprenderme una vez más"” (22 de junio del 2003: II, 165).

Guy Scarpetta es un visitante frecuente de su casa. Durante el período de preparación de Le temps retrouvé, el invitado opina, discute y propone ideas acerca de Proust. No hay evidencia de que Ruiz las tome en cuenta. Pero el 28 de septiembre de 1999 anota: "He leído atenta- 
mente el artículo de Guy Scarpetta en Positif. Impresionante hasta qué punto ha seguido los meandros de mi trabajo en Le temps retrouvé" (I, 357). ¡Era que no!

En enero de 2003 da cuenta de una serie de entrevistas que le da a otro crítico amigo, Benoît Peeters: “...duró una hora y media. Evocamos los años de cineasta durante la UP" (II, 99). Después de su muerte, Scarpetta y Peeters publicaron un elegante libro constituido por algunos análisis sobre películas selectas y la extensa entrevista de Peeters. ${ }^{6}$ Era que no.

En octubre de 1998: "Mientras esperaba a Matteo leí un par de capítulos del libro sobre Ozu de [Youssef] Ishaghpour. Me deprimí. En un momento descarta todo el cine occidental por dramático y subjetivo y, por lo tanto, no cine. Me sentí atacado. Esos libros permiten remover siempre mi fondo moralista y me hacen sentir culpable y frívolo" (I, 305). Seis meses después almuerza con Ishaghpour, que en los años siguientes escribirá algunos de los más agudos y favorables textos críticos sobre Ruiz. ${ }^{7}$ Era que no.

En algún momento, los festivales europeos, en los que las películas de Ruiz han estado siempre presentes, parecen rebelarse: en 2005, Le domaine perdu es rechazada en Locarno, Berlín y Cannes, "lo que me cuesta entender, porque es una de las películas de las que estoy más contento" (II, 369). El mismo año Klimt es rechazada en Venecia: "No me queda más que aceptar que los enemigos existen" (II, 374). Tres años después, Venecia rechaza también Nucingen Haus: "De a poco me van marginalizando. Pero sigo resistiendo contra el cine UnescoBenetton (...) La contienda es desigual" (II, 535).

Sería difícil imaginar estos (y otros muchos) rasgos de Ruiz sin que él mismo los hubiera dejado ver. No hay que atribuirlo al descuido: éste es un Diario extraordinariamente autoconsciente, sobre cuyo sentido se interroga el autor una y otra vez. En algún caso llega hasta el autorretrato, como el 22 de abril de 1996: "He leído algunas páginas de este diario tratando de ubicar el punto en que empiezo a volverme per-

\footnotetext{
${ }^{6}$ Guy Scarpetta y Benoît Peeters, Raoul Ruiz, le magicien (París: Les Impressions Nouvelles, 2015).

${ }^{7}$ En verdad, Ishaghpour había mostrado su admiración por L'hypothèse du tableau volé en el número especial de Cahiers du Cinéma de 1983. Su texto se puede hallar en Valeria De los Ríos e Iván Pinto, eds., El cine de Raúl Ruiz. Fantasmas, simulacros y artificios (Santiago: Uqbar Editores, 2010).
} 
sonaje. No hay tal punto: el personaje aparece y desaparece. ¿Quién es? De lo que leemos nos enteramos que lee mucho (no es cierto), que tiene una enorme curiosidad (trata de tenerla), que padece de inclinaciones a la pose (exacto, pero ¿qué pose?)" (II, 111).

Es un Diario que se extravía una y otra vez y que por eso produce un raro efecto de desequilibrio entre años y meses. El año con más volumen de páginas (146) es 2001, uno de los pocos en que sólo concluyó una película; el 2003, cuando terminó cuatro cintas, ocupa 130 páginas. Pero 1994 se agota en 13 páginas y el 2006, en 43, siendo años de alta producción fílmica. Aun teniendo en cuenta los fragmentos que no fue posible descifrar y los varios cuadernos perdidos, ¿cabría acaso esperar un documento más euclidiano de Raúl Ruiz?

El aspecto doloroso del Diario son los proyectos no realizados: las experiencias que pudieron ser las adaptaciones de Stevenson (Dr. Jekyll $\& M r$. Hyde) y Chesterton (El hombre que fue jueves) o, en un cineasta que admiró la forma histórica de Rossellini en Hechos de los Apóstoles, sus versiones de Port-Royal, Cagliostro y Sacher-Masoch.

Aunque nada resulta tan inspirador como un párrafo del 24 de abril del 2006 acerca de un proyecto para el cual quizás no exista un cineasta más adecuado: "Notas para La Gabriela: 1) Archivos de voces de radio. 2) Micrófonos (Marcos de Aguirre). 3) Maquillaje de época (Crema del Harem, Ponds, Glostora, gomina Brancato, jugo de limón). 4) Afiches de propaganda. 5) Cronologías varias. 6) Motores de autos de la época. 7) Motores de trenes. 8) Nieve, lluvia, viento. 9) Instrumentos médicos de la época. 10) Pregones. 11) Volantines. 12) Empedrados. 13) Teléfonos. Estructura en doble espiral y en friso" (II, 436).

El Diario de Ruiz es una obra literaria sólo a medias, en cuanto que su otra mitad son las películas, pero es la memoria creativa más interesante jamás producida por un cineasta, desde la austera Linterna mágica, de Ingmar Bergman, hasta la hilarante Mi último suspiro, de Luis Buñuel; desde las elusivas Memorias inmorales, de S.M. Eisenstein, hasta la cómica Cómo hice un centenar de películas en Hollywood y nunca perdí un centavo, de Roger Corman; desde la reflexiva Mi vida y mi cine, de Jean Renoir, hasta la chismosa Por dentro do Cinema Novo, de Paulo César Saraceni.

Hay que rechazar la tentación de decir que el Diario de Ruiz es su última gran película. No es así. El cine escrito es tan imposible como su 
contrario. En algún momento Ruiz declara su nostalgia por los Diarios (1969) fílmicos de Jonas Mekas, otro formidable cineasta con el que se admiraban mutuamente. Pero Ruiz decidió escribir y esa elección tiene ahora una resonancia diferente, el valor de un testamento que ni él mismo, ni sus lectores, llegarán a comprender enteramente, porque es una voz que sigue luchando contra lo indecible, la ausencia, la muerte, la maldita una sola muerte. EP 